This item was submitted to Loughborough's Research Repository by the author.

Items in Figshare are protected by copyright, with all rights reserved, unless otherwise indicated.

\title{
Structural performance of a steep slope landfill lining system
}

PLEASE CITE THE PUBLISHED VERSION

PUBLISHER

(C) Institution of Civil Engineers / Thomas Telford

VERSION

VoR (Version of Record)

LICENCE

CC BY-NC-ND 4.0

REPOSITORY RECORD

Dixon, Neil, Samson Ng'ambi, and D. Russell V. Jones. 2019. "Structural Performance of a Steep Slope Landfill Lining System”. figshare. https://hdl.handle.net/2134/4617. 
This item was submitted to Loughborough's Institutional Repository (https://dspace.lboro.ac.uk/) by the author and is made available under the following Creative Commons Licence conditions.

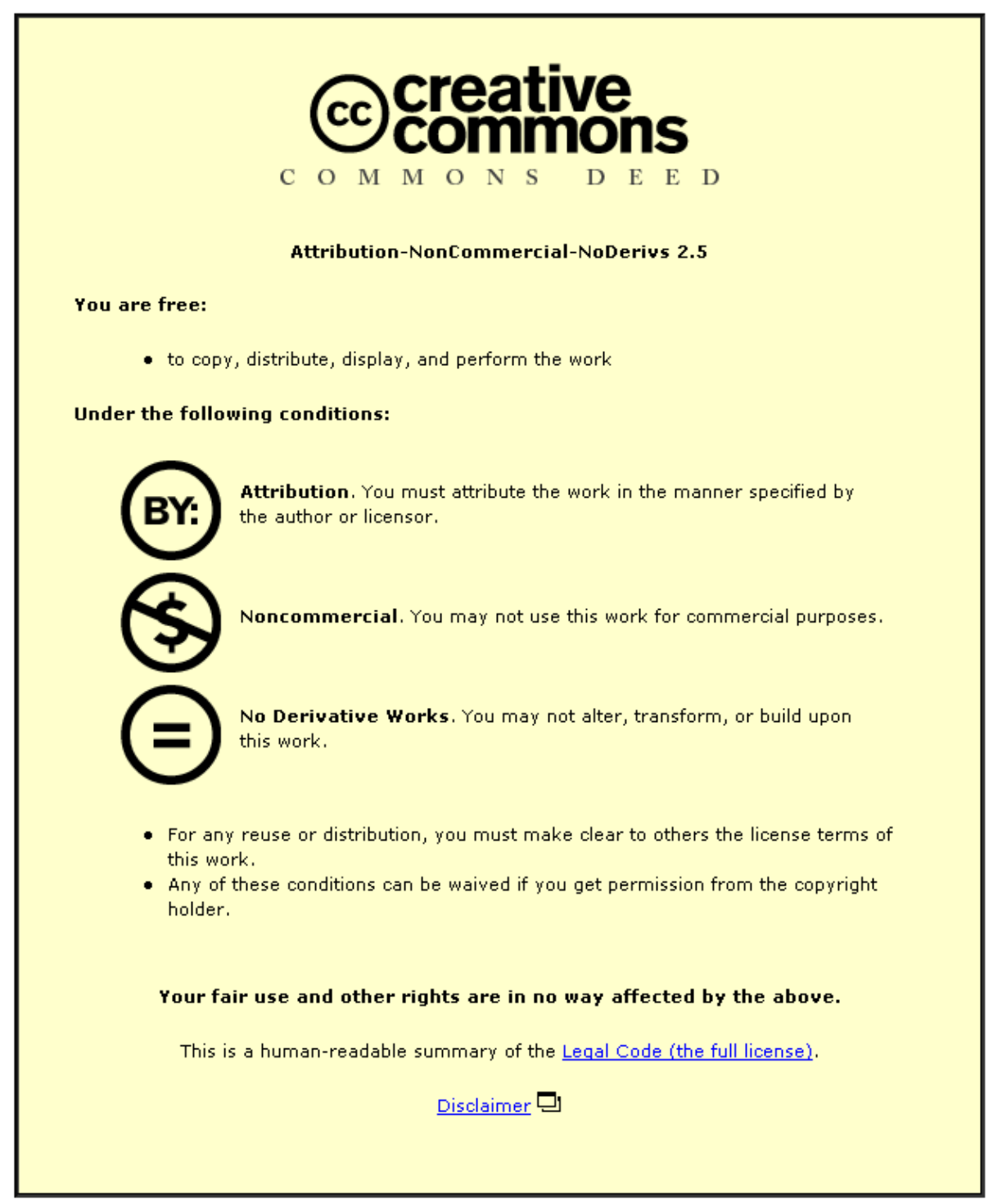

For the full text of this licence, please go to: http://creativecommons.org/licenses/by-nc-nd/2.5/ 


Proceedings of the Institution of
Civil Engineers
Geotechnical Engineering 157
July 2004 Issue GE3
Pages I I5-125
Paper 13567
Received 12/1 I/2003
Accepted 05/02/2004
Keywords:
geotechnical engineering/landfill

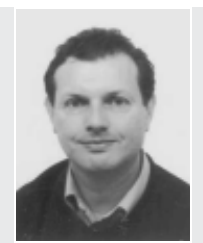

Neil Dixon

Senior Lecturer in Geotechnical Engineering, Department of Civil and Building Engineering, Loughborough University, UK

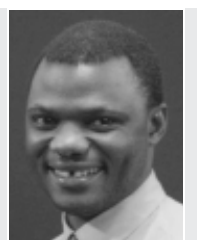

Samson Ng'ambi lecturer in Geotechnics, School of Science and the Environment, Coventy University, UK (formerly Research Assistant, Loughborough University)

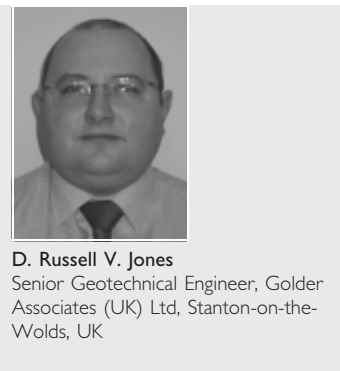

\section{Structural performance of a steep slope landfill lining system}

\section{N. Dixon BSc, PhD, FGS, S. Ng'ambi MSc, PhD and D. R. V. Jones MSc, PhD, MICE, FGS, ACIArb}

The stability and integrity of a landfill barrier, in both the short and the long term, are vital to performance as a containment system for leachate and landfill gas, and are a requirement of the UK permitting process. The structural performance of steep, non-self-supporting barrier systems depends in part on the adjacent waste body for lateral support. This paper presents the results of an investigation into structural performance during construction of a typical UK mineral steep slope landfill lining system. Instrument installation, monitoring and results are presented. Measurements and observations have shown shear and overturning modes of clay barrier failure, leading to loss of integrity. Normal stresses measured at the waste/barrier interface demonstrate that waste adjacent to the barrier provides low and variable lateral support. It is concluded that this has led to the observed failure mechanisms. Temporary conditions during phased construction are shown to be critical. This investigation has demonstrated that current UK municipal solid waste, placed using standard practices, cannot by itself provide sufficient support to ensure the integrity of a clay barrier in a steep slope lining system. Waste/barrier interaction must be considered as part of the design process.

\section{NOTATION}

$K_{0} \quad$ coefficient of earth pressure at rest

$K_{\mathrm{W}} \quad$ pressure coefficient for municipal solid waste (ratio of horizontal effective stress to vertical effective stress)

\section{INTRODUCTION}

Increasing demand in the UK for landfill facilities for the disposal of waste has led to the use of void spaces with steep side walls, such as quarries. The stability and integrity of a landfill barrier system, in both the short and the long term, are vital to performance as a containment system for leachate and landfill gas, ${ }^{1}$ and are a requirement of the Environment Agency permitting process. The stability and structural integrity of steep, non-self-supporting barrier systems depend in part on the adjacent waste body for lateral support. Mineral liners are still used in the UK to line such slopes, and these fall into the 'non-self-supporting' category. The use of mineral layers in steep slope lining systems is likely to continue as a result of the recent EC Landfill Directive. ${ }^{2}$ This stipulates that all non-hazardous and hazardous landfills should incorporate a geological barrier. Where this cannot be provided by the in-situ material (e.g. in highly permeable strata), an engineered mineral layer is required to act as the geological barrier. The challenge for the designer is to produce a cost-effective, practical solution for these multi-layered systems. The structural integrity of such lining systems is influenced by the construction sequence and mechanical properties of the adjacent waste body, with waste stiffness being a key parameter. ${ }^{3}$ Designers must understand the distribution and magnitude of the barrier/waste interaction effects so that the integrity of the lining system as a barrier to leachate and gas can be ensured throughout its design life.

To date there exists only limited detailed information on the structural performance of steep slope barrier systems during construction, waste placement and operation. A large-scale laboratory trial was undertaken by Edelmann et al. ${ }^{4}$ to investigate the interaction between a specific design of steep slope barrier system and waste for a proposed landfill in Germany, and the results were compared with performance of the actual barrier system obtained by monitoring. The barrier design investigated was a compacted clay liner supported by a gabion wall installed on a slope of $80^{\circ}$. The findings from this detailed study included the following:

(a) The barrier experienced significant vertical and horizontal strains, with the magnitude dependent on the stiffness of the waste body.

(b) The method of construction, including the phasing of barrier construction and supporting waste lifts, had an influence on the magnitude and distribution of barrier deformations.

(c) Differential strains were found in the barrier components.

(d) Various potential failure mechanisms were predicted resulting from the magnitude of deformations required for equilibrium between the barrier and waste body to be reached (Fig. 1).

It was concluded from this study that stability (i.e. ultimate limit state) and integrity (i.e. serviceability limit state) must be examined for each barrier design separately, and should be checked by appropriate in-situ measurements. Despite this recommendation, and evidence that problems have occurred as a result of movements in steep slope lining systems, ${ }^{1}$ up to now very few-if any-barriers have been instrumented in the UK in order to confirm acceptable structural performance. 


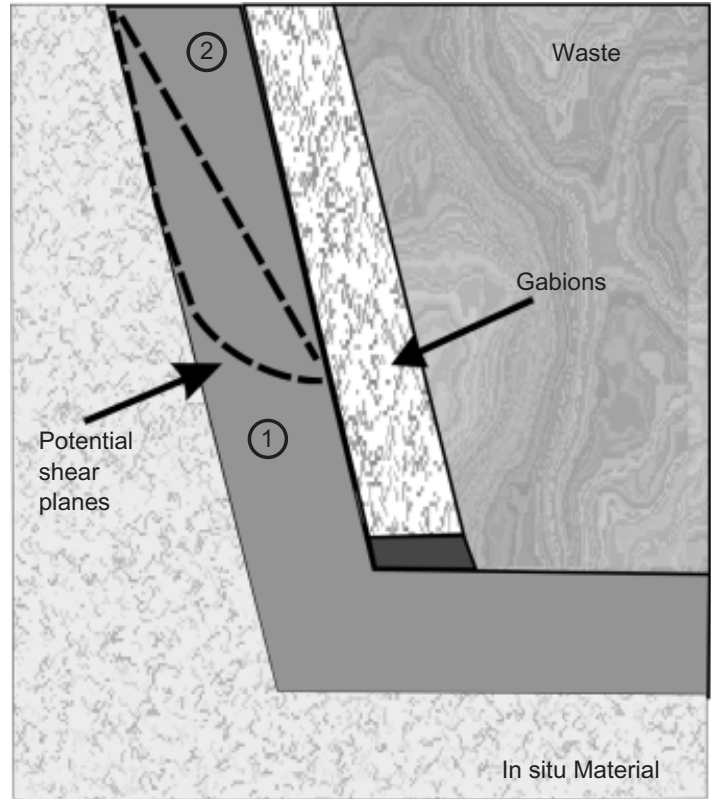

(a)

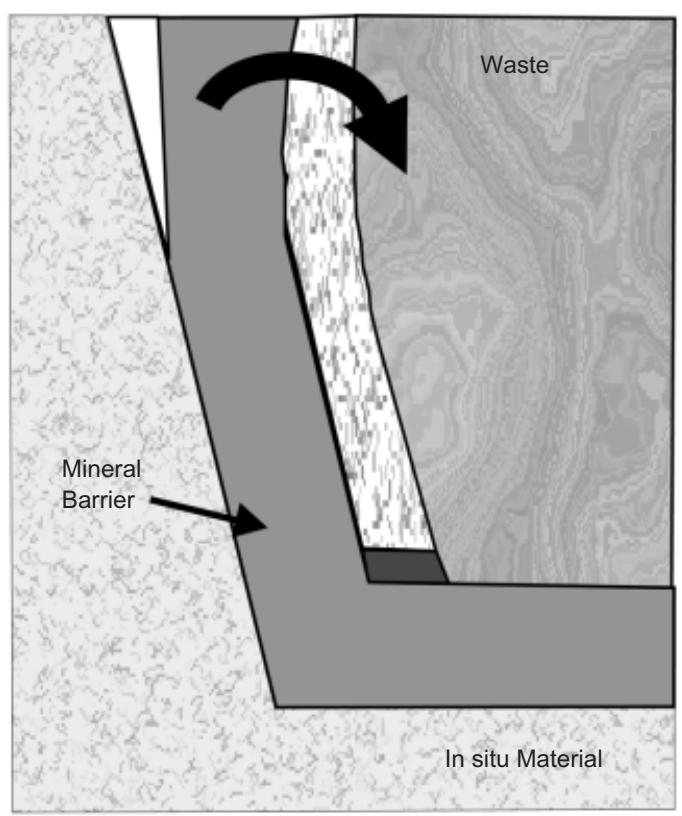

(c)

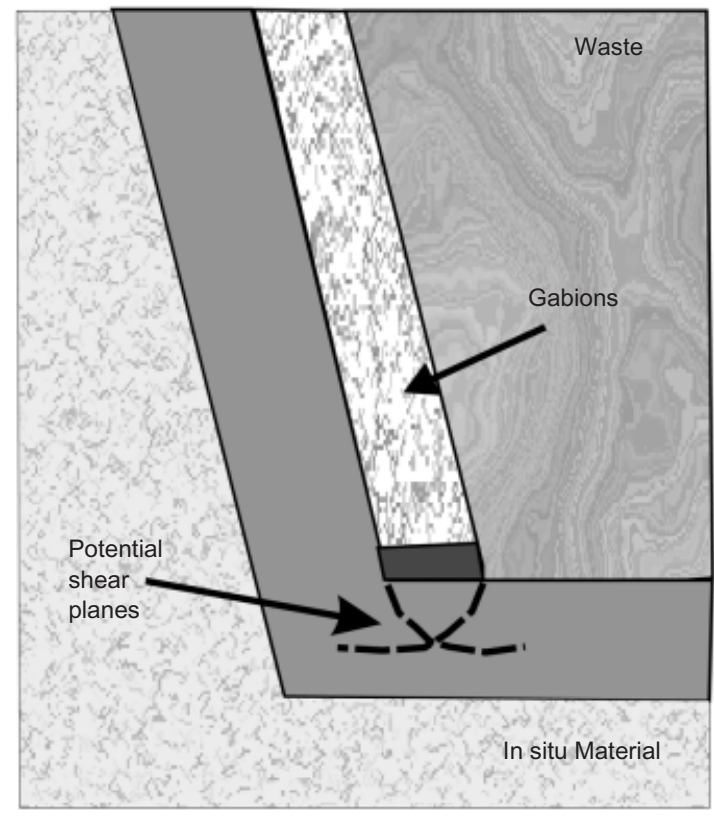

(b)

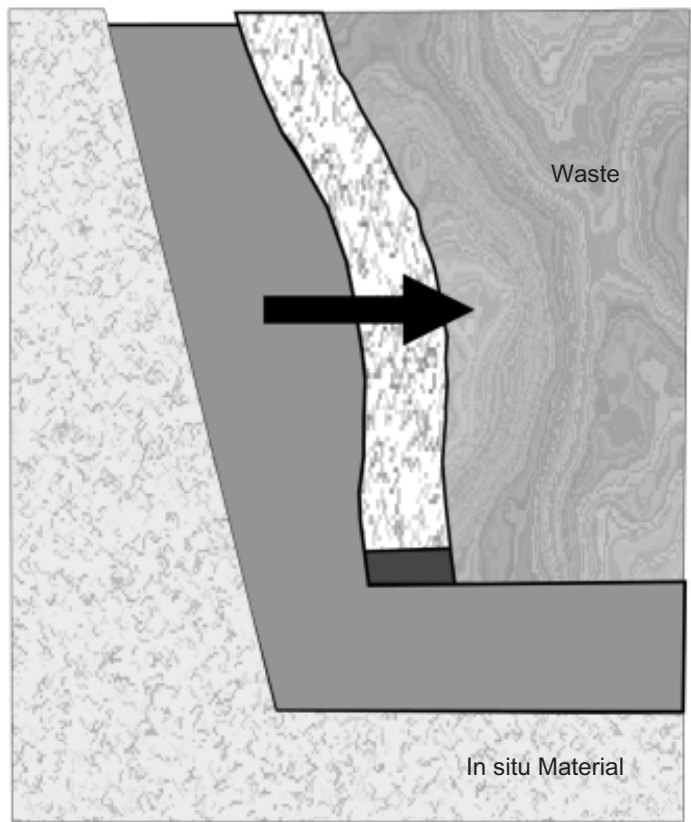

Fig. I. Potential failure mechanisms of a steep slope mineral barrier system (after Edelmann et al. ${ }^{4}$ ): (a) shear failure; (b) bearing capacity failure; (c) overturning; (d) bulging

This paper presents the results from an investigation of structural performance during construction of a typical UK mineral steep slope landfill lining system. The study extends the work of Edelmann et al. ${ }^{4}$ by measuring stresses in the waste and at the waste/barrier interface in addition to considering the deformation of the barrier components and waste body. The paper describes the instrument installation and monitoring process, presents the results and their interpretation, and summarises the main findings. Key issues to be considered by designers of steep slope lining systems are highlighted.

\section{SITE DESCRIPTION}

The barrier system instrumented was in a cell constructed as part of a non-hazardous landfill in Nottinghamshire, England. The barrier was constructed in a quarry formed in weak sandstone. Fig. 2 shows the quarry immediately before lining works commenced. The cell had a base area $100 \mathrm{~m} \times 75 \mathrm{~m}$, average slope angles of $70^{\circ}$, and a maximum slope height of $28 \mathrm{~m}$ on the west side. It was the final cell to be constructed at this site. The barrier design was the same as used in the construction of previous cells. Collection rounds of household waste were delivered to site from the Nottinghamshire county 


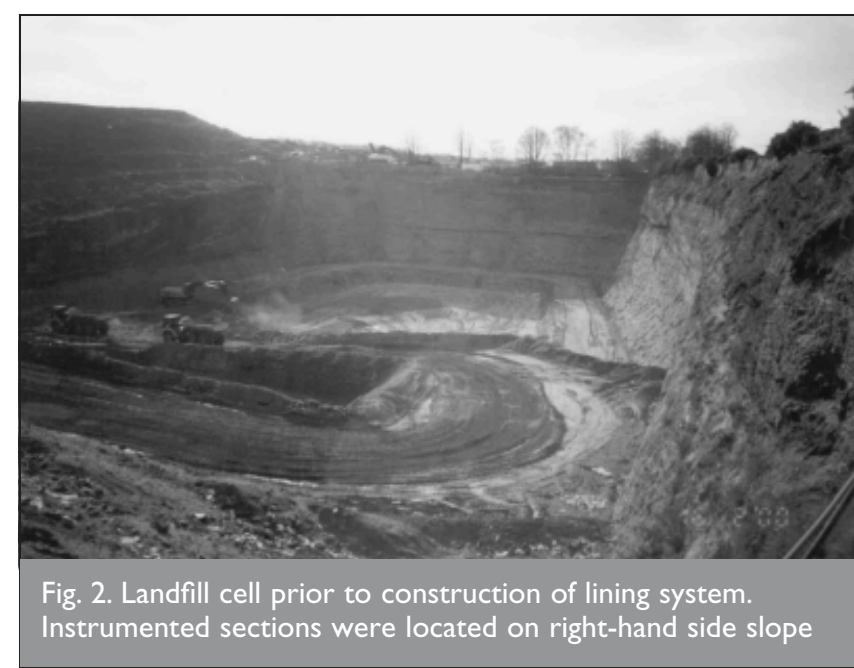

area, and this resulted in the waste being predominantly municipal solid waste (MSW): vegetable matter (food waste and garden trimmings), wood, paper, textiles, metals, glass, dust, cinder, soil and plastic. There was also a small percentage (5-10\%) of industrial waste: chipboard, hardboard, concrete, demolition rubble, metals and glass. Sand was used as temporary daily cover layers, although these were of limited thickness.

The lining system design comprised a fine-grained soil layer (silty clay) compacted against the quarry wall with a minimum horizontal thickness of $1.2 \mathrm{~m}$, with a layer of inert waste (typically fine to coarse sand with fine to coarse gravel and some organic content and occasional brick, metal and plastic) placed against the clay layer with a nominal horizontal thickness of $1 \mathrm{~m}$. The inert waste was designed to protect the clay barrier from damage (i.e. puncture) by waste particles. MSW was placed directly against the inert waste (i.e. there was no side slope drainage layer). On the base and $3 \mathrm{~m}$ up the side slope, the lining system comprised a single HDPE geomembrane overlain by a sand drainage layer $0.5 \mathrm{~m}$ thick.

The side slope barrier was constructed in nine lifts, nominally $3 \mathrm{~m}$ high, with waste placed against each lift of the barrier before the next lift was formed. The final waste profile is approximately $3 \mathrm{~m}$ higher than the side wall barrier, sloping up to this height with an angle of about $20^{\circ}$. A geomembrane cover was constructed in Spring 2003.

The mineral liner was constructed using silty clay of intermediate plasticity, with placement specification designed to achieve a minimum permeability of $1 \times 10^{-9} \mathrm{~m} / \mathrm{s}$. The authors are not aware of any shear strength criteria being specified, although shear vane tests were carried out. Testing of the clay was conducted as part of the CQA to ensure compliance with the acceptance criteria. The measured ranges of properties of the compacted clay barrier (Symonds, personal communication, 2001) were: bulk density $2 \cdot 06-2 \cdot 18 \mathrm{Mg} / \mathrm{m}^{3}$; plastic limit 19-24\%; liquid limit 43-47\%; plasticity index 22-27\%; moisture content $12 \cdot 6-20 \cdot 5 \%$; clay content 33\%; and shear vane $120-140 \mathrm{kPa}$.

\section{BARRIER CONSTRUCTION AND WASTE PLACEMENT}

The barrier was formed by tipping clay along the quarry wall and spreading it in layers not exceeding $250 \mathrm{~mm}$ and with a layer width of $3 \cdot 0-3 \cdot 5 \mathrm{~m}$. Compaction was carried out using a towed vibrating sheepsfoot roller for the first seven lifts and a smaller, hand-operated sheepsfoot roller for lifts 8 and 9. The compacted material was placed layer upon layer to approximately $3 \mathrm{~m}$ in height for each lift. Once the $3 \mathrm{~m}$ height was achieved, the clay was trimmed using a hydraulic excavator. The trimmed crest width of the barrier was a minimum of $1.2 \mathrm{~m}$, and the external slope angle was typically less than that of the quarry wall in order to ensure the required minimum thickness, as shown in Fig. 3. This produced the characteristic 'Christmas tree' shape of the clay barrier. After completion of each lift of the clay barrier, the inert waste fill material was placed against the barrier within $48 \mathrm{~h}$ of trimming. The layer of inert material was not compacted, and often did not achieve a minimum thickness of $1 \mathrm{~m}$ at the top of the lift.

Waste was placed against the inert material within 5 days, with the aim of providing additional support to the clay barrier. Waste was end-tipped by collection lorries and subsequently pushed and spread by a $31 \mathrm{t}$ Komatsu CL310 bulldozer and simultaneously compacted with its sheepsfoot steel wheels by a small number of passes. (Following the site being taken over by a new operator the effort used to compact the waste was increased: that is, waste lifts 7 onwards.) The waste is considered to have moderate to good compaction, ${ }^{5}$ with an average unit weight of $9 \mathrm{kN} / \mathrm{m}^{3}$.

\section{INSTRUMENTATION AND MONITORING STRATEGY}

The rationale of monitoring at this site was to measure the behaviour of the barrier primarily during construction but also in the longer term. The instrumentation and monitoring were designed to answer the following key questions:

(a) What are the stresses in the waste, and at the barrier/waste interface?

(b) What are the deformations in the clay barrier and the adjacent waste body?

The magnitude and distribution of the parameters both spatially (i.e. at different points up the barrier) and in time (i.e. stages of construction) were required. The aim was to enable 
the effects of the construction process to be assessed. The following instruments were installed to monitor aspects of behaviour:

(a) inclinometer casings to measure the lateral deformations of the clay barrier, the inert waste and the MSW

(b) extensometer magnets to measure settlement of the barrier and of the MSW, and differential settlement at the barrier/ inert waste interface

(c) vibrating wire pressure cells to measure both the vertical and horizontal in-situ stresses in the MSW, and the normal stress at the clay barrier/inert waste interface.

Instruments were installed at two sections of the barrier (Sections 1 and 2) located $15 \mathrm{~m}$ apart on the west side of the quarry (right-hand side of the quarry as shown in Fig. 2). Fig. 4 shows the position of instruments from both sections on a composite cross-section through the barrier. The installation programme was an integral part of the construction process, with instruments installed during barrier construction and waste placement. Fig. 5 shows instrument installation in progress. Installation commenced during construction of the bottom lift in June/July 2000 and was completed in December 2001 following construction of the ninth lift and waste placement. The final height of the clay barrier at the instrumented sections is $23 \mathrm{~m}$.

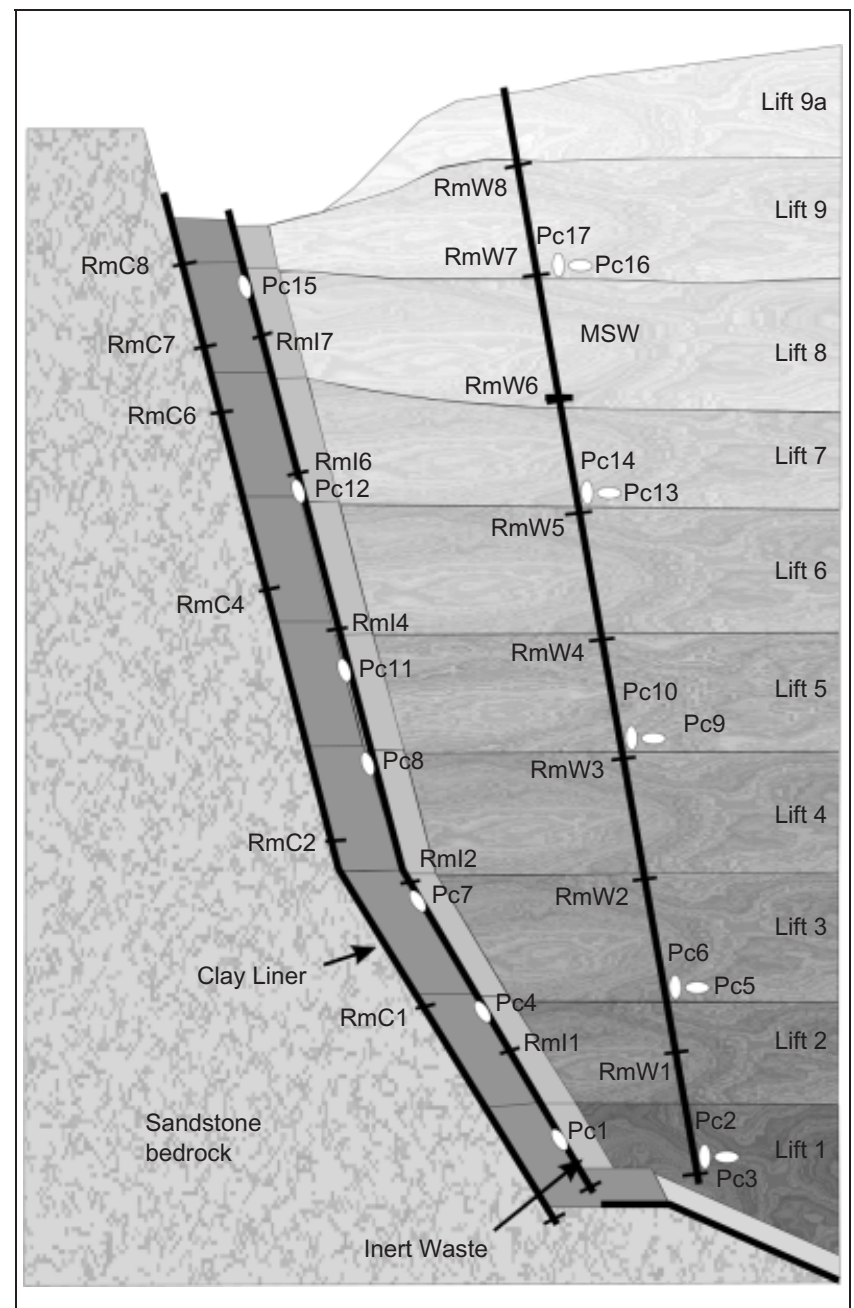

Fig. 4. Schematic composite cross-section showing instrument locations

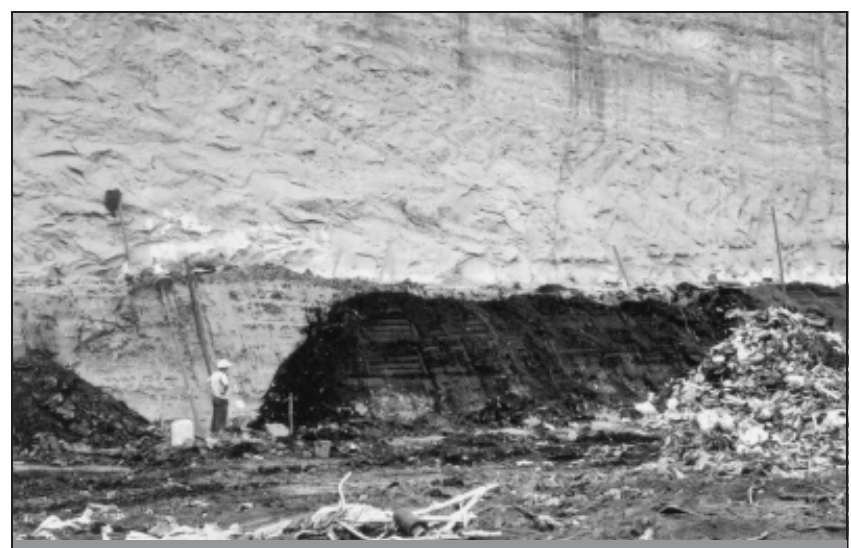

Fig. 5. Installation of inclinometer casings and a pressure cell on the clay/inert waste interface

\section{I. Inclinometer casing and ring magnet installation}

Three inclinometer casings were installed at each section, one at the back face of the clay barrier next to the quarry wall, a second at the front face of the clay barrier at the barrier/inert fill interface, and a third in the waste body. Casings and ring magnets were embedded in barrier material and waste during construction. As a result of the construction method employed (i.e. initial compaction of $3 \mathrm{~m}$ width of clay, subsequently cut back to $1.2 \mathrm{~m}$ wide) the inclinometer casings at the inert waste/ clay interface, and the pressure cell cables, were buried and subsequently exhumed following construction of each lift.

\subsection{Pressure cell installation}

Pressure cells (hydraulic devices $300 \mathrm{~mm}$ in diameter) were installed on the clay planar cut surface at the clay barrier/inert fill interface and in the MSW. Cells installed in the waste were orientated to measure either vertical or horizontal stresses. They were placed in sand filled bags in order to distribute potential point loads from large waste particles. Pressure cell cables were bundled together and run to the crest of the barrier through a conduit pipe placed against the face of the barrier (Fig. 5). Loops of cable were provided in an attempt to minimise stresses in the cables generated by settlement of the waste body.

\subsection{Monitoring}

Monitoring of the pressure cells commenced immediately after installation, and the settlement measurements started following construction of lift 3. The delay in obtaining settlement readings was a result of operational constraints, which restricted access to the inclinometer casings. Monitoring was continued throughout the construction and waste placement period. As a result of the aggressive conditions under which the instruments were installed and operated, a significant percentage were damaged, and hence only truncated periods of measurement are available for some of the instruments.

\section{MEASURED BEHAVIOUR}

\section{I. Stresses in MSW}

Pairs of pressure cells measuring horizontal and vertical stresses were installed in four lifts of MSW (e.g. Pc2/Pc3 in lift 1, Pc5/Pc6 in lift 3, Pc9/Pc10 in lift 5 and Pc16/Pc17 in lift 9). These have provided unique measurements of the ratio between in-situ vertical and horizontal stresses. Effective stresses have 
been measured as all cells were located above the leachate level. Values of the pressure coefficient $K_{\mathrm{w}}$ for MSW have been calculated from each pair of cells ( $K_{\mathrm{w}}=$ horizontal effective stress/vertical effective stress). Calculated values of $K_{\mathrm{w}}$ are plotted in Fig. 6 against height of waste above measuring point. Most of the $K_{\mathrm{w}}$ values produced by all four pairs of pressure cells are between 0.6 and $1 \cdot 0$. The values of $K_{\mathrm{w}}$ are relatively constant with depth of burial for cells Pc2/Pc3 and Pc16/Pc17, whereas Pc5/Pc6 and Pc9/Pc10 show a trend of increasing $K_{\mathrm{w}}$ with depth. Damage to the cables caused by waste settlement has limited the number of calculated values.

The reason for the trend of increasing $K_{\mathrm{w}}$ with vertical stress recorded by two of the pairs of cells is unclear. The measurements may be reflecting a real phenomenon or a limitation of the instrumentation. It is possible that the cells orientated to measure horizontal stress are rotating. This would result in higher measured stresses and hence higher calculated $K_{\mathrm{W}}$ values. Another consideration is that the cells may be influenced by waste settlement against the sloping barrier, or by barrier movements. As discussed below, these mechanisms will tend to increase horizontal stresses. However, these mechanisms are not thought to be modifying the horizontal stresses in the waste at the measurement locations because the waste has a low stiffness, ${ }^{3}$ and the cells are several metres from

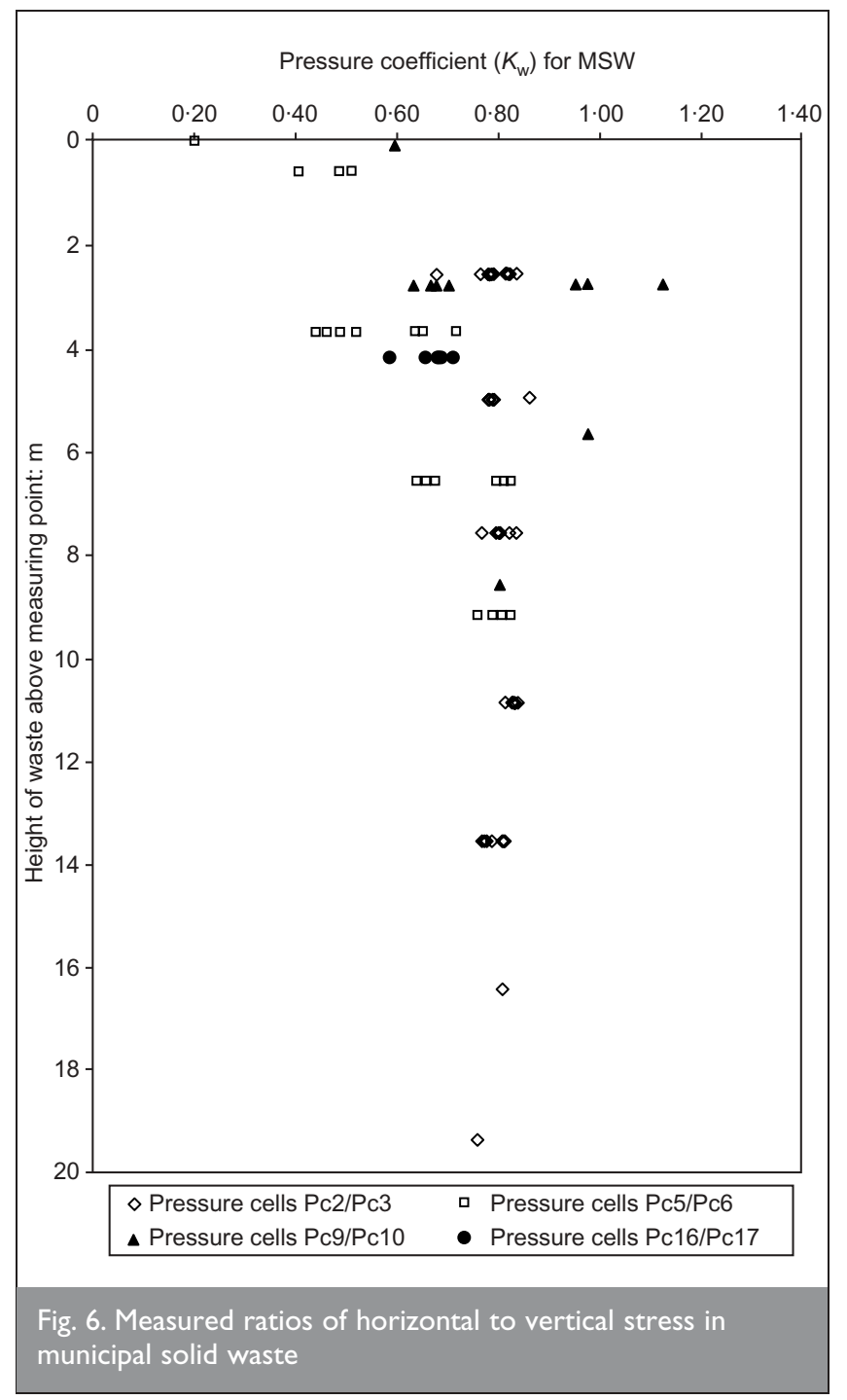

the barrier. The pair of cells closest to the barrier (Pc2 and Pc3) have produced constant values of $K_{\mathrm{w}}$. If it is accepted that the barrier has not influenced the measured stresses in the waste, then the pressure coefficients could be considered values of earth pressure at rest.

The $K_{\mathrm{w}}$ values obtained from pairs of cells located in different lifts show excellent agreement considering the heterogeneous nature of MSW, the large size of some elements of waste, and the relatively small size of the pressure cells. There are no values of in-situ pressure coefficient for MSW reported in the literature for comparison. Landva et al. ${ }^{6}$ reported measured lateral earth pressures at rest of reconstituted MSW in largescale laboratory experiments, and obtained $K_{0}$ values around $0 \cdot 4$. The low value obtained was explained as being a result of the reinforced structure of MSW. It was proposed that the greater the degree of reinforcement, the lower the values of $K_{0}$. The in-situ values obtained in this study do not appear to follow this trend. The MSW at this site contains a significant percentage of reinforcing type-particles (e.g. textiles, paper and plastic), but it is likely that large strains will be required to mobilise tensile stresses in these randomly orientated elements. It may be the smaller particles forming the matrix that control at rest horizontal stresses. Further work is required to investigate the factors controlling in-situ horizontal stresses in MSW.

\subsection{Stress conditions at the clay barrier/inert waste interface}

Deformation of the clay component of a 'non-self-supporting' barrier system, and hence its integrity, is controlled by the degree of support provided by the waste. This is influenced by the initial stress conditions at the barrier/waste interface and the stiffness behaviour of MSW (i.e. this controls the magnitude of deformations required to establish equilibrium conditions between the clay and waste). Pressure cells were positioned at this interface in order to measure normal stresses during the construction process. Fig. 7 shows the measured pressures during and following construction. Instruments from both sections are included. A clear response is shown to periods of barrier construction. These are the first measured stresses acting on a steep slope barrier system to be published.

Figure 8 shows distributions of normal stress acting on the clay barrier at stages of construction, and after construction and waste placement have been completed. This is a composite plot combining measurements made on Sections 1 and 2. The points marked on the vertical axis indicate the height of barrier construction at the time of measurement. This plot shows that the stresses acting on the barrier are variable, with very low normal stresses at locations with limited waste overburden (e.g. less than $6 \mathrm{~m}$ ). Fig. 8 shows low stresses in the upper waste layers following lifts 3, 4, 5, 6 and 7. This is an important finding, because it demonstrates that during construction the waste provides limited support to the barrier. With increased waste overburden the normal stresses increase significantly. The stress history of the barrier must be modelled as part of the design process if stability and integrity issues are to be fully investigated. Designs based on consideration of only the final barrier/waste profile will underestimate deformation of the clay barrier. 


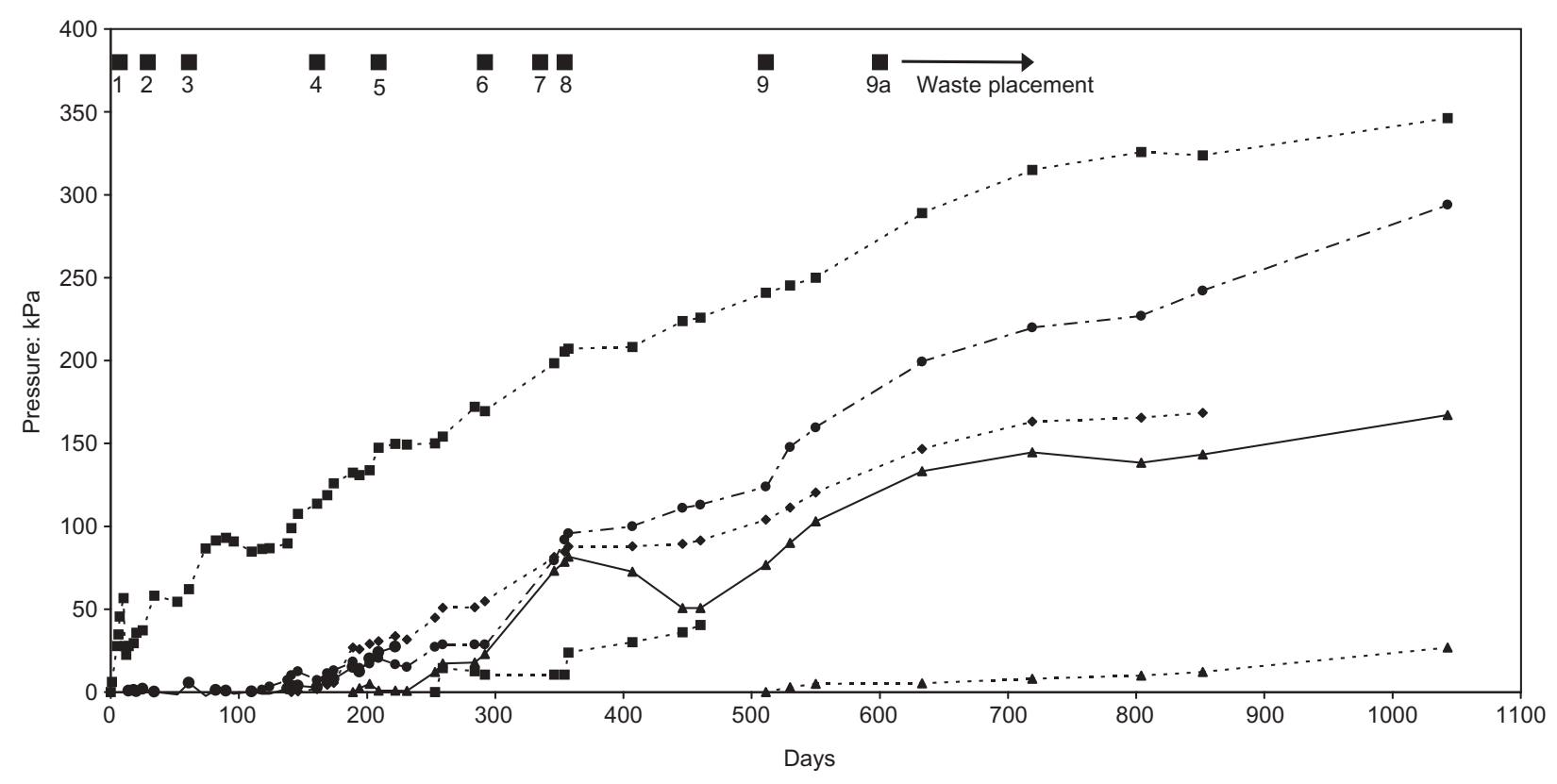

\begin{tabular}{|c|c|c|}
\hline 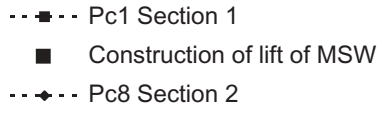 & $\begin{array}{l}\text { - - - Pc7 Section } 1 \\
\ldots-\text { - Pc15 Section } 1 \\
\text { - - - Pc12 Section } 2\end{array}$ & $\begin{array}{l}\longrightarrow \text { Pc11 Section } 1 \\
\longrightarrow \text { Pc4 Section2 }\end{array}$ \\
\hline
\end{tabular}

Fig. 7. Normal stress on clay barrier/inert waste interface during and following construction

Pressure cell Pc1 located at the base of the side slope consistently recorded stresses higher than those in the waste at the same level measured by Pc2 and Pc3. The waste adjacent to the barrier at this level is constrained by the bench on which the side slope lining system sits, and this has resulted in higher lateral stresses being generated as the waste compresses. Monitoring of the surviving pressure cells continued after barrier construction and showed that normal stresses at the clay/inert interface continued to increase at every level. Two mechanisms could be contributing to the observed significant increases in stress on the barrier following completion of construction:

(a) As waste settles adjacent to the sloping barrier it compresses laterally, thus leading to increases in horizontal stress.

(b) Movement of the clay barrier towards the waste will generate higher lateral stresses.

The latter will occur if the barrier requires additional support from the waste to achieve equilibrium. Evidence for horizontal movement of the clay barrier into the waste is discussed below.

\subsection{Settlements}

Settlement monitoring did not commence until after completion of lift 3, and therefore the measured cumulative settlements do not include deformations that occurred during the initial lifts. Fig. 9 shows examples of cumulative settlements measured at the back of the clay barrier, in the inert waste, and in the MSW. Similar behaviour was measured in both sections.
For lifts 1 to 8 settlements in the clay barrier were typically less than $50 \mathrm{~mm}$ immediately beneath a newly constructed lift, and were often significantly less. For subsequent lifts, sections of the barrier more than one lift below the newly constructed layer experienced much-reduced settlements (i.e. typically $<10 \mathrm{~mm}$ ). This demonstrated that the main component of measured settlements in the clay results from the compaction of the clay barrier in the lift immediately above. However, in Section 1, settlements of $43 \mathrm{~mm}$ were measured in lift 8 immediately following construction of lift 9, and a further $270 \mathrm{~mm}$ occurred over the next few weeks (e.g. RmC7 in Fig. 9). Section 2, Lift 9, experienced similar behaviour, with $80 \mathrm{~mm}$ immediately following construction of lift 9 and a further $350 \mathrm{~mm}$ over the following weeks. At both sections rates of settlement were decreased significantly by placement of waste above the level of the completed barrier (i.e. lift 9a). The large settlements of the clay barrier are an indication of instability and a loss of integrity, as discussed below.

There are limited settlement data for the inert waste owing to distortion and blockage of the access casings. The available data show settlements in the region of $200-400 \mathrm{~mm}$ in the inert waste following construction of a new lift immediately above. Settlements are significantly less in response to construction of subsequent lifts. As with the clay behaviour, construction activities have been shown to have the largest influence on the inert waste settlements. The large settlements in the inert waste indicate instability and are consistent with the fact that it was not compacted and hence had an initial loose state. The inert waste layer also acts as a transition zone between the clay and large settlements in the MSW. 


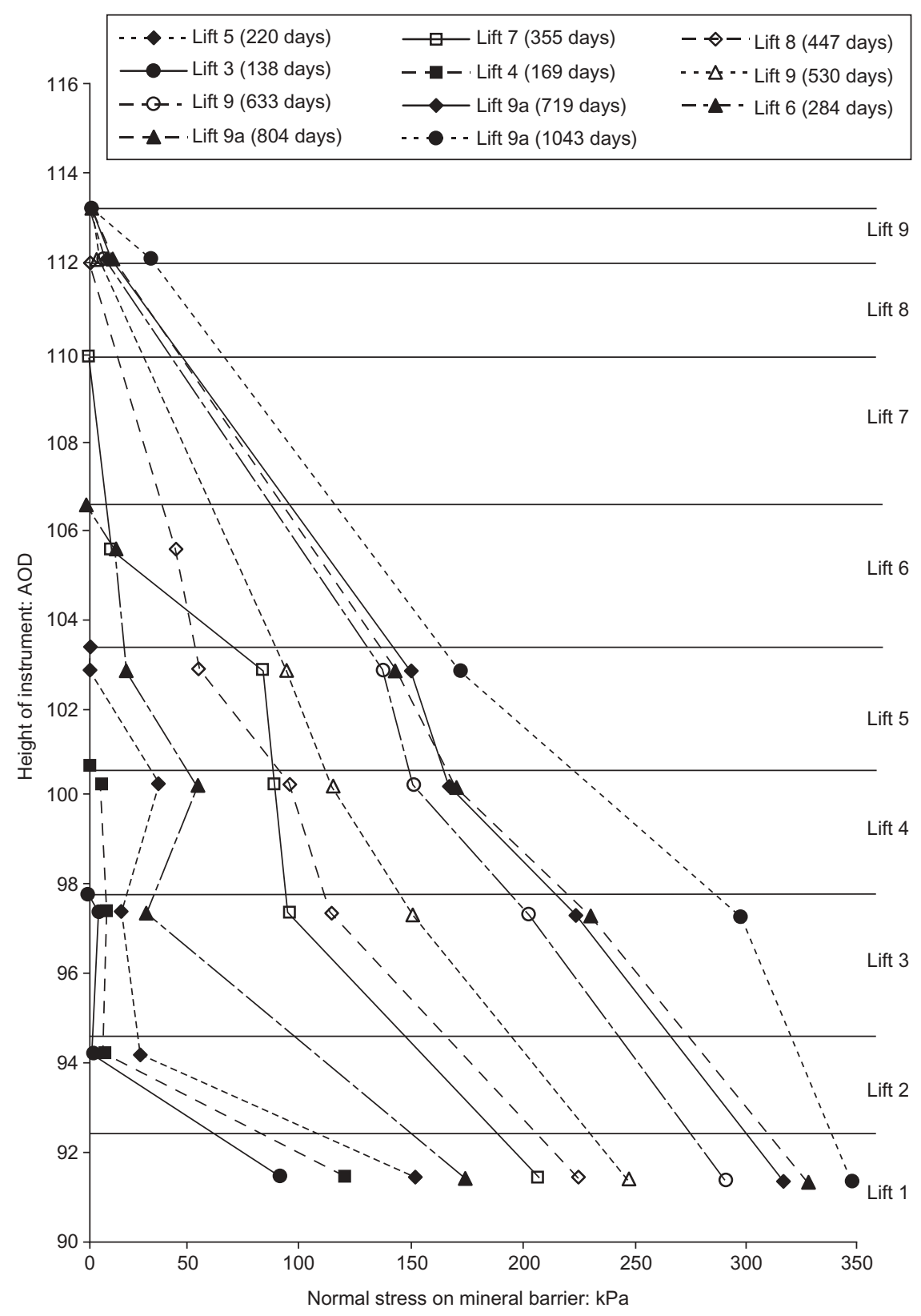

Fig. 8. Distributions of normal stress on clay barrier/inert waste interface during and following construction

Limited data are available for MSW settlements at large overburden pressures for the same reasons as for the inert waste. Settlements in the range $300-700 \mathrm{~mm}$ have been measured in response to placement of a nominally $3 \mathrm{~m}$ layer of waste immediately above. Loading can be assumed to be onedimensional, as waste layers were placed over a large area compared with their thickness. Subsequent lifts of waste produced reducing settlements (e.g. in the order of $150 \mathrm{~mm}$ and $100 \mathrm{~mm}$ for the second and third lifts respectively: see RmW plots in Fig. 9). These settlement data have been used to calculate values of drained constrained modulus for MSW. Values from Sections 1 and 2 are plotted in Fig. 10 against the mean vertical stress in the layer. Also shown are values obtained from the literature. ${ }^{7-9}$ Values from the two sections are comparable, and there is limited scatter. In comparison with values from the literature, the slope of the relationship between constrained modulus and mean vertical stress is steeper, but it is encouraging that individual data points are still within the range of reported values. Most of the data in the literature are from element tests on disturbed waste samples, and it is to be expected that waste stiffness will differ as a result of variations in waste constituents, grading and placement methods.

\subsection{Lateral deformations}

Inclinometer casings were installed to measure horizontal deformations of the clay barrier, inert waste and MSW during construction. The first readings were attempted following completion of lift 3. Unfortunately it was found that all the casings had profiles too curved to insert the standard biaxial inclinometer probe to any depth. The casings behind the clay barrier had been deformed by compaction of the clay against the undulating surface of quarry wall. Casings in the inert waste and MSW deformed during placement of the backfill surround and construction of subsequent lifts. Fig. 11 shows a section of distorted casing that was exposed by careful 


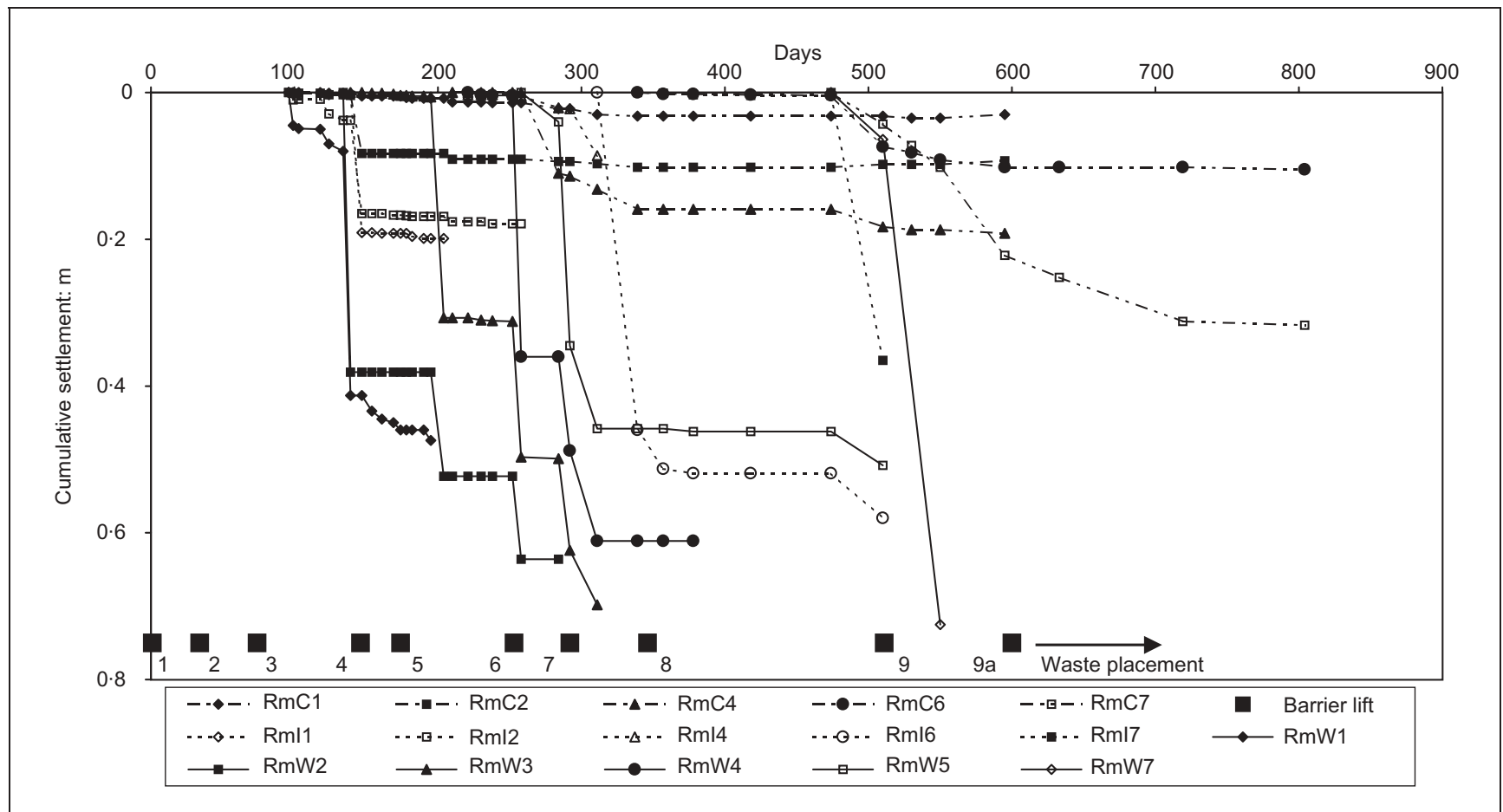

Fig. 9. Cumulative settlements for clay barrier, inert waste and municipal solid waste during construction

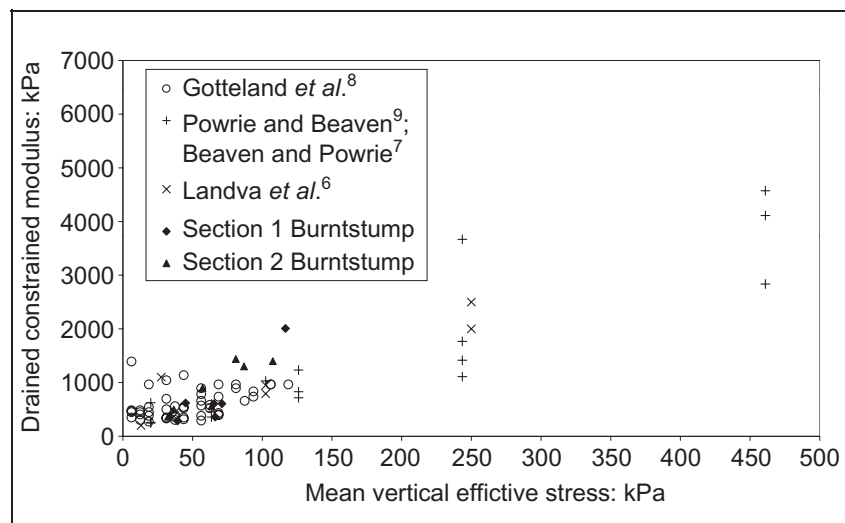

Fig. 10. Drained constrained modulus values for municipal solid waste

excavation to find the cause of a constriction. No direct measurements of casing deformations were obtained. However, it was possible for the magnetic extensometer probe to access the casings, and this allowed the settlement measurements discussed above to be obtained. In addition, this also provided information on the location of constrictions in the casings, which denote zones of significant barrier deformation. Fig. 12 shows the location of deformation zones for the clay barrier and inert waste in Section 2 indicated by casing constrictions. Also shown are the timing of movements in relation to the phases of construction. The magnitude of barrier deformations is demonstrated by the fact that traces of clay were found on the probe at the level of the casing constriction in lift 6 , Section 2. This indicates that deformations were sufficiently severe to shear the casing and presumably the clay barrier. Also of note was a constriction in the casing behind the clay barrier at the level of lift 6 , Section 1 . The base of this casing was accessible until 4 months after the completion of all construction activities. This provides clear evidence of postconstruction movement in the clay barrier, and demonstrates

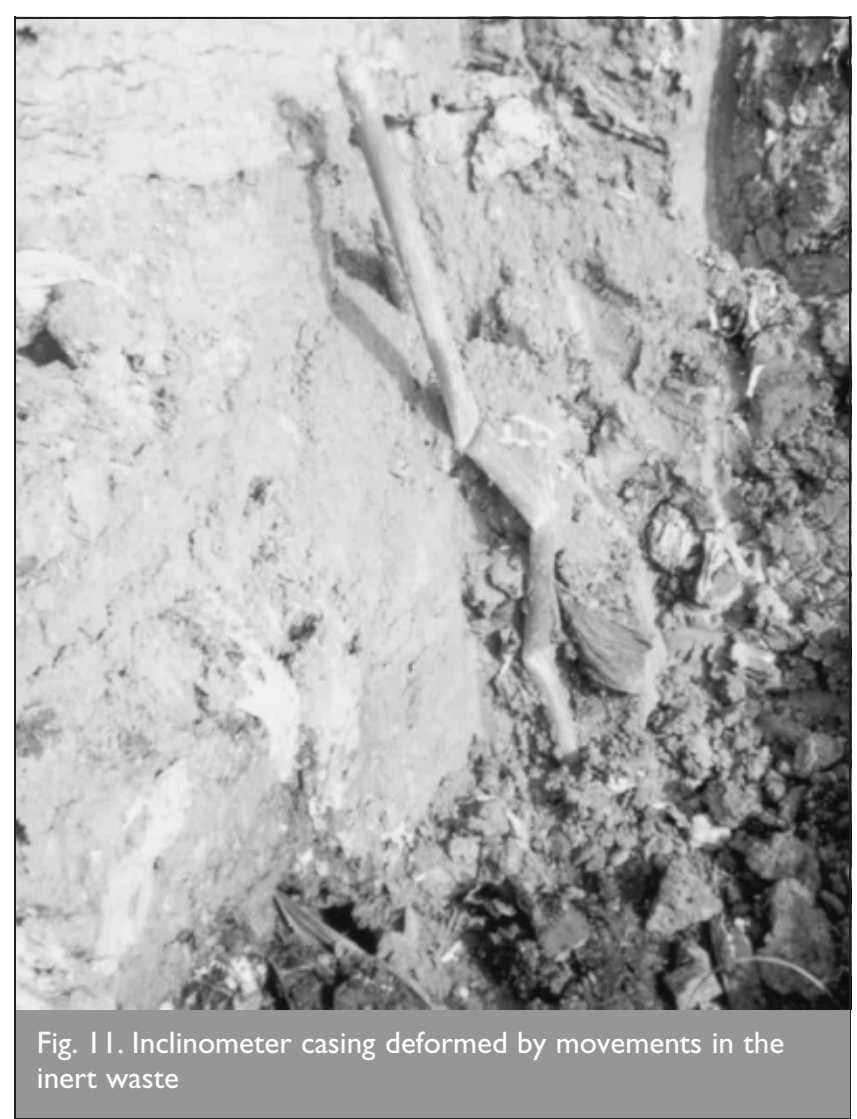

that the barrier was not fully supported by MSW even when waste was placed to the final construction level.

Additional evidence of barrier deformations was provided by the tension crack that formed at the back of the clay barrier during lifts 7, 8 and 9 (Fig. 12). The crack extended for several tens of metres and went through both sections (Fig. 13). The tension crack was repaired by removal and reconstruction of lift 7, but it reappeared following construction of lift 8 . 


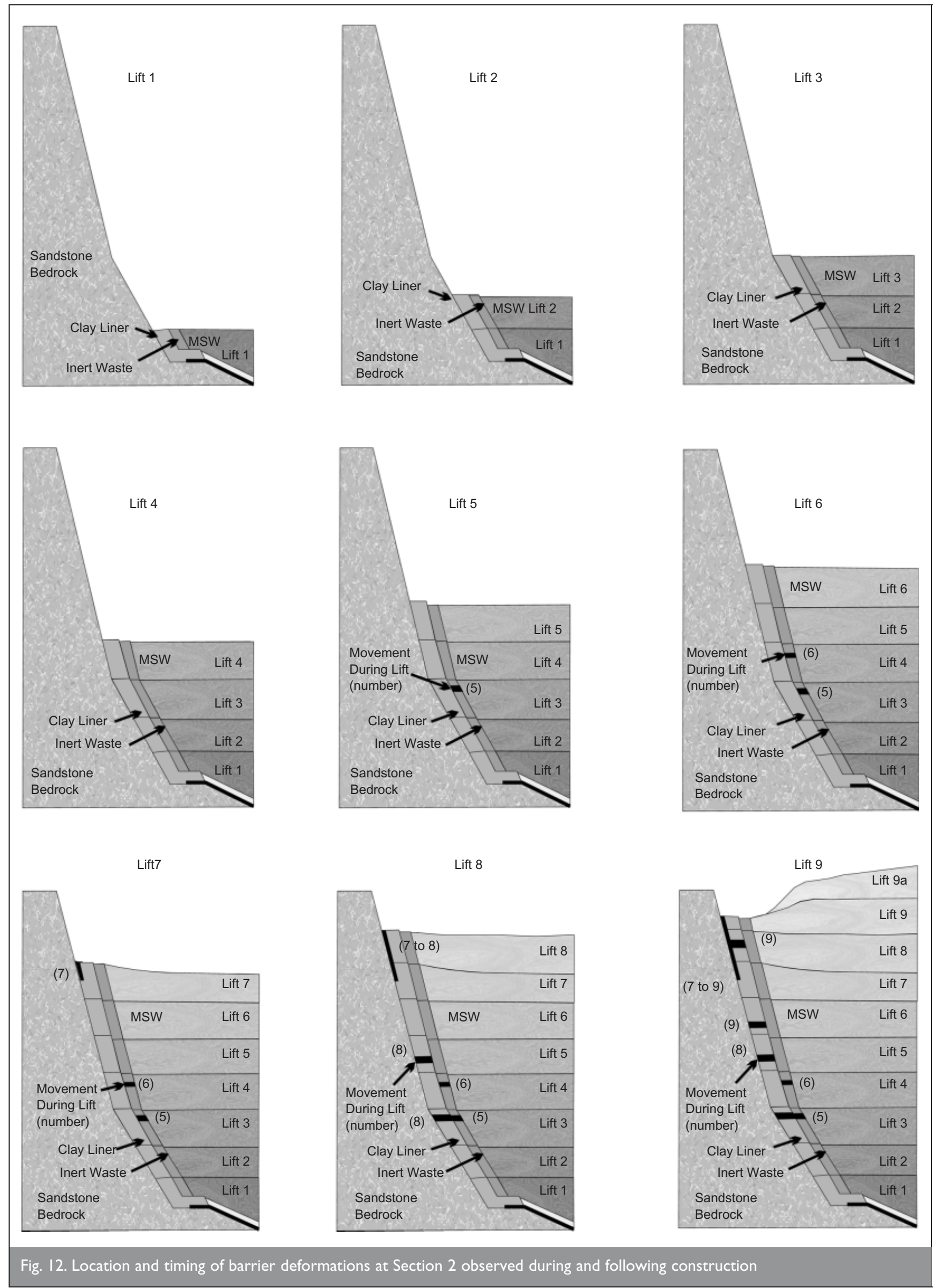

Further proof that the integrity of the barrier had been compromised by deformations was provided by the presence of gas venting from the casing installed behind the clay barrier in Section 2.

\section{DESIGN AND CONSTRUCTION ISSUES}

The design and method of construction of the clay barrier lining system investigated in this study are typical of those used in several UK landfills. The waste type (i.e. MSW) and 


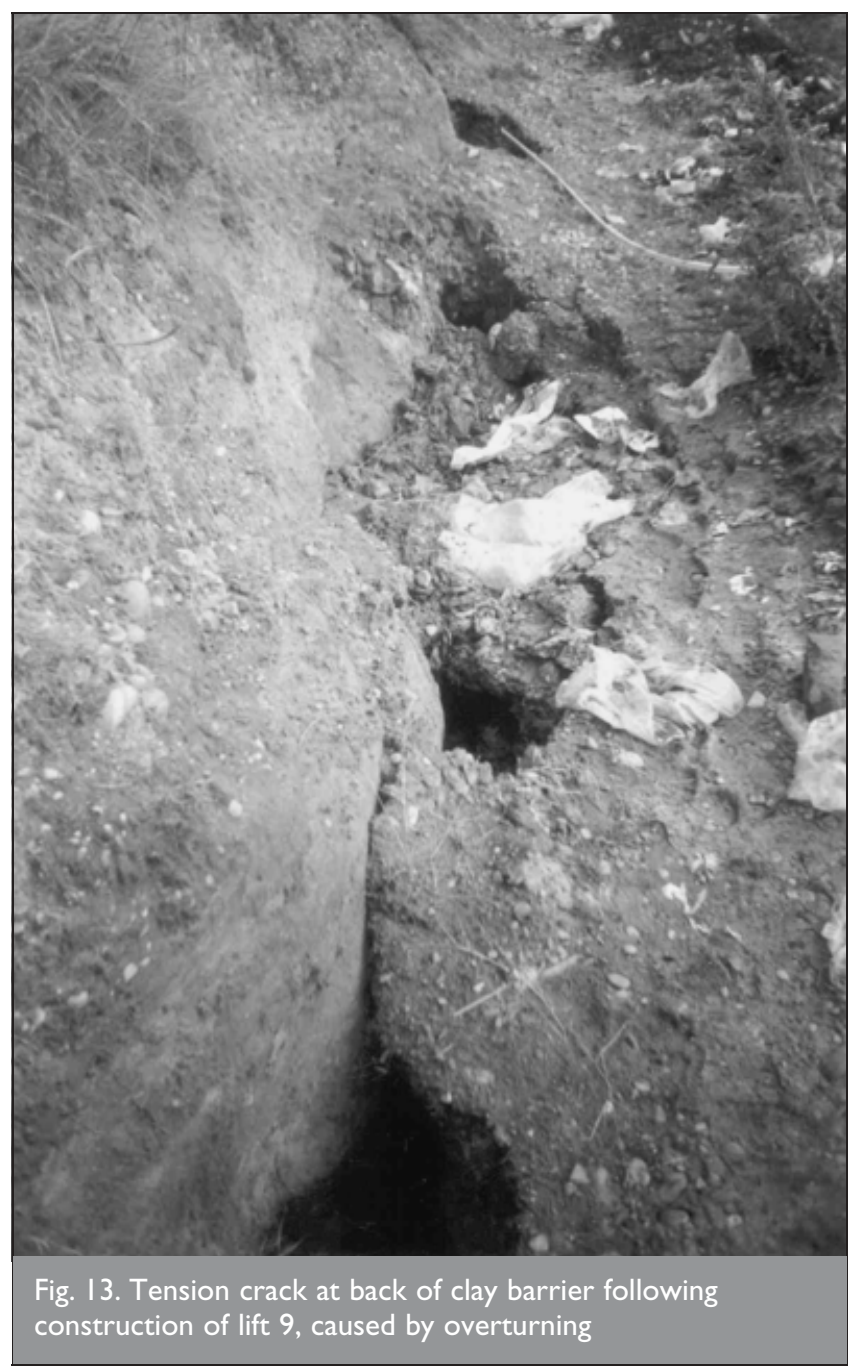

method of waste placement and compaction are also typical of standard UK practice. Evidence obtained from visual assessment by Environment Agency staff of this type of lining system used in a number of landfills ${ }^{1}$ has indicated that the clay barrier can suffer significant deformation, even after waste placement. This is consistent with the findings of the study by Edelmann et al. ${ }^{4}$ of a similar system used in Germany. The current study has confirmed the relevance of the Edelmann et $a l .{ }^{4}$ investigation and conclusions to UK practice. However, in addition it has provided information on waste/barrier interaction during staged construction, and has shown the controlling role of stresses in the waste body and at the waste/ clay barrier interface.

This investigation has demonstrated failure of the clay barrier via loss of integrity. Shear and overturning modes of failure predicted by Edelmann et al., ${ }^{4}$ and shown in Fig. 1, have been inferred or observed. There is insufficient evidence to conclude whether bulging has also taken place. The waste adjacent to the barrier provides insufficient lateral support to the clay liner, and the above mechanisms result. Temporary conditions during phased construction are critical. Low lateral stresses have been measured at the interface between waste and clay barrier for conditions of limited overburden. Although the stresses increased significantly at higher overburden depths and with time, clay barrier deformations continued for several months after completion of waste placement. Stresses in waste adjacent to the barrier are low because limited compaction effort is used. This is a result of concern that compaction activities might damage the barrier. In the absence of detailed measurements of lateral displacement of the barrier it is not clear whether the measured increases in lateral stress following construction are due to settlement of the waste or to movement of the barrier into the waste body.

The results of this investigation have significant implications for all steep slope lining system designs that incorporate engineered geological barriers (i.e. lining systems compliant with the Landfill Directive ${ }^{2}$ ). Present-day MSW in the UK, placed using current practice, does not provide sufficient lateral support to ensure the stability and integrity of lining systems incorporating a clay component. Hence 'non-selfsupporting' lining systems should not be used unless it can be demonstrated as part of the design that engineered material (i.e. either fill or processed MSW) placed next to the barrier will provide the required support. The design must consider temporary conditions during phased construction. A positive outcome of the investigation is the evidence that horizontal stresses in the main body of MSW may be significantly higher than previously thought-that is, earth (waste) pressure at rest coefficients in the region of $0 \cdot 8$. Further measurements are required, but if these higher values are confirmed, and waste can be compacted against the barrier without causing damage, this will be advantageous for landfill designers, allowing them to incorporate greater support from the waste in designs than has previously been the case. ${ }^{10}$

\section{CONCLUSIONS}

Design and construction of Landfill Directive compliant steep slope lining systems are a major challenge. The incorporation of an engineered geological barrier, or clay primary barrier, requires rigorous assessment of the support conditions. Behaviour during construction is critical to long-term performance. This investigation has demonstrated that MSW placed using standard practices cannot by itself provide sufficient support to ensure the integrity of the barrier. Waste/ barrier interaction must be considered as part of the design process. Numerical modelling techniques provide an appropriate tool for assessing the deformations in, and hence integrity of, the lining system. This study has provided information on horizontal stresses in MSW and also on stiffness, which can be used in conjunction with the increasing body of MSW data in the literature to develop an appropriate material model for use in numerical analyses.

Current good practice, as defined by the Environment Agency guidance, ${ }^{1}$ requires that steep slope lining systems be instrumented in order to demonstrate acceptable structural performance. It is only by monitoring lining systems both during and after construction that stability and integrity can be demonstrated. This study has shown that it is possible to install and monitor instrumentation during staged construction of a steep slope barrier, and that appropriate data can be obtained.

\section{ACKNOWLEDGEMENTS}

The work described in this paper was funded by a research grant from the UK Engineering and Physical Sciences Research Council (GR/M33570). The project was also supported by the Environment Agency, Golder Associates (UK) Ltd, and Waste 
Recycling Group. Special thanks are due to Andrew Connell for his help with installing the instruments and the production of Fig. 10.

\section{REFERENCES}

1. JONES D. R. V. and DIXON N. Stability of Landfill Lining Systems: Literature Review. Environment Agency, 2003, Research and Development Project P1-385, Report 1.

2. Council of the European Union. Council Directive of 26 April 1999 on the landfill of waste (1999/31/EC). Official Journal of the European Communities, 1999, L182/1.

3. Dixon N., Jones D. R. V. and WhitTLE R. Mechanical properties of household waste: In situ assessment using pressuremeters. Proceedings of the 7th International Waste Management and Landfill Symposium, Sardinia, 1999, 453-460.

4. Edelmann L., Hertweck M. and Amann A. D. Mechanical behaviour of landfill barrier systems. Proceedings of the Institution of Civil Engineers-Geotechnical Engineering, 1999, 137, 215-224.

5. Fassett J. B., Leonardo G. A. and Repetto P. C. Geotechnical properties of municipal solid waste and their use in landfill design. Proceedings of the Waste Technical Conference-Landfill Technology, National Solid Waste Management Association, Charleston, SC, 1994, 1-29.

6. LandVA A. 0., VAlsangKar A. J. and PelKeY S. G. Lateral earth pressure at rest and compressibility of municipal solid waste. Canadian Geotechnical Journal, 2000, 37, 1157-1165.

7. BEAVEn R. P. and Powrie W. Hydrological and geotechnical properties of refuse using a large scale compression cell. Proceedings of the 5th International Landfill Symposium, Sardinia, 1995, 745-760.

8. GotTeland P., Gachet C. and Vuillemin M. Mechanical study of a municipal solid waste landfill. Proceedings of the 8th International Waste Management and Landfill Symposium, Sardinia, 2001, 424-433.

9. POWRIE W. and BEAVEN R. P. Hydraulic properties of household waste and implications for landfills. Proceedings of the Institution of Civil Engineers-Geotechnical Engineering, 1999, 137, 235-247.

10. JONES D. R. V. and DiXON N. The long term stability of landfill side slopes. Proceedings of the 6th International Waste Management and Landfill Symposium, Sardinia, 1997, 3, 517-523.

Please email, fax or post your discussion contributions to the secretary: email: mary.henderson@ice.org.uk; fax: +44 (0)20 665 2294; or post to Mary Henderson, Journals Department, Institution of Civil Engineers, I-7 Great George Street, London SWIP 3AA. 